\title{
IMPLEMENTASI MODEL ACTIVE LEARNING TEKNIK LEARNING STARTS WITH A QUESTION UNTUK MENINGKATKAN AKTIVITAS BELAJAR
}

\section{THE IMPLEMENTATION OF ACTIVE LEARNING MODEL LEARNING STARTS WITH A QUESTION TO IMPROVE LEARNING ACTIVITY}

\author{
Oleh: \\ Fenti Noor Endah Kurniawati \\ Prodi Pendidikan Akuntansi Universitas Negeri Yogyakarta \\ phen.fenti@gmail.com \\ Rr. Indah Mustikawati \\ Staf Pengajar Jurusan Pendidikan Akuntansi Universitas Negeri Yogyakarta
}

\begin{abstract}
Abstrak
Penelitian ini merupakan Penelitian Tindakan Kelas yang bertujuan meningkatkan Aktivitas Belajar Akuntansi Peserta Didik Kelas XI IPS 3 SMA Negeri 5 Yogyakarta Tahun Ajaran 2013/2014 melalui implementasi Model Active Learning dengan Teknik Learning Starts With A Question. Pengumpulan data dalam penelitian ini dilakukan dengan observasi partisipatif dan angket. Analisis data yang digunakan adalah analisis data deskriptif kuantitatif dengan persentase. Berdasarkan hasil penelitian dapat disimpulkan implementasi Model Active Learning dengan Teknik Learning Starts With A Question dapat meningkatkan Aktivitas Belajar Akuntansi. Hal ini dibuktikan dengan data penelitian yang menunjukkan adanya peningkatan pada semua indikator Aktivitas Belajar Akuntansi peserta didik. Peningkatan ini juga terlihat dari rata-rata Aktivitas Belajar Akuntansi peserta didik pada siklus I sebesar 66,48\% meningkat pada siklus II menjadi sebesar 82,34\%. Berdasarkan data angket Aktivitas Belajar Akuntansi peserta didik juga terjadi peningkatan pada siklus I sebesar 67,44\% dan pada siklus II menjadi sebesar 79,88\%.
\end{abstract}

Kata kunci: Learning Starts With A Question, Aktivitas Belajar Akuntansi

\begin{abstract}
This research is a Classroom Action Research that is aims to improve Accounting Learning Activity of XI Social 3 students of SMA Negeri 5 Yogyakarta in the academic year 2013/2014 through the implementation of Active Learning Model with Learning Starts with a Question Techniques. The data were collected by participative observation and questionnaires. The data were analyzed by descriptive quantitative with percentage. Based on the results of this research, it can be concluded that Active Learning Model implementation with Learning Starts with a Question Techniques can improve Accounting Learning Activity. The evidence of this research is the increase of all indicators Accounting Learning Activities Learners. The increase was also seen from the average learner Accounting Learning Activities in the first cycle that increased of $66,48 \%$ and in the second cycle it become $82,34 \%$. Based on the questionnaire data of Accounting Learning Activity the students also had increased in the first cycle from 67,44\% and in the second cycle it become 79,88\% .
\end{abstract}

Keywords: Learning Starts With a Question, Accounting Learning Activity 


\section{PENDAHULUAN}

Pendidikan pada hakikatnya merupakan suatu usaha sadar untuk mencetak generasi yang berkualitas sesuai dengan tuntutan perkembangan zaman. Pendidikan menjadi penting karena pendidikan memegang peranan utama dalam pembentukan manusia yang tanggap terhadap lingkungan dan peka terhadap perubahan yang terjadi di sekitarnya. Seiring dengan semakin majunya ilmu pengetahuan dan teknologi, pendidikan menjadi salah satu indikator suatu negara tergolong sebagai negara yang baik sumber daya manusianya. Pendidikan nasional di Indonesia harus sesuai dengan tujuan pendidikan nasional yang tertuang dalam Undang-Undang Nomor 20 tentang Sistem Pendidikan Nasional pasal 3:

Pendidikan Nasional berfungsi mengembangkan kemampuan dan membentuk watak serta peradaban bangsa yang bermanfaat dalam rangka mencerdaskan kehidupan bangsa, bertujuan untuk berkembangnya potensi peserta didik agar menjadi manusia yang beriman dan bertakwa kepada Tuhan Yang Maha Esa, berakhlak mulia, sehat, berilmu, cakap, kreatif, mandiri, dan menjadi warga negara yang demokratis secara bertanggung jawab (Oemar Hamalik, 2009: 131-132). Tujuan pendidikan akan dapat tercapai melalui peran aktif semua pihak yang terlibat yaitu orang tua, tenaga pendidik, peserta didik, pemerintah, masyarakat, dan fasilitas yang memadai.

Pendidikan dapat diperoleh melalui pendidikan informal, pendidikan formal, maupun pendidikan nonformal. Pendidikan informal adalah pendidikan yang diperoleh dari pengalaman sehari-hari secara sadar maupun tidak sadar yang berlangsung seumur hidup. Pendidikan formal adalah pendidikan yang diperoleh secara teratur, bertingkat, dan terdapat peraturan-peraturan tertentu secara ketat. Pendidikan nonformal adalah pendidikan yang diperoleh dengan cara tertentu dan sadar tetapi tidak terdapat peraturan-peraturan yang ketat (Abu Ahmadi dan Nur Uhbiyati, 2003: 97). Pendidikan yang paling banyak diikuti adalah pendidikan formal, yaitu pendidikan yang dilaksanakan di kelas dan terdapat interaksi antara guru dan peserta didik. Interaksi dalam proses pembelajaran seharusnya berlangsung secara dua arah antara guru dan peserta didik, sehingga aktivitas belajar peserta didik dapat optimal. Kenyataannya, interaksi pembelajaran berlangsung searah dan peserta didik hanya menjadi objek pembelajaran sehingga aktivitas belajar peserta didik menjadi rendah. Rendahnya aktivitas belajar peserta didik tersebut disebabkan oleh beberapa faktor, diantaranya kondisi psikologis peserta didik, media pembelajaran yang digunakan guru, dan cara guru mengajar di kelas.

Guru sebagai seorang pengajar harus mampu memilih model pembelajaran yang tepat, sehingga potensi diri peserta didik dapat dikembangkan secara optimal. Berdasarkan pengamatan yang dilakukan pada pembelajaran akuntansi, guru di SMA Negeri 5 Yogyakarta kurang bervariasi dalam menerapkan model pembelajaran sehingga peserta didik cenderung merasa jenuh saat berlangsungnya proses pembelajaran. Akibatnya, peserta didik lebih senang mengobrol dengan temannya atau bermain handphone daripada memperhatikan guru menjelaskan materi pelajaran. Selain itu, guru masih dominan menggunakan model pembelajaran konvensional berupa ceramah dan kurang memanfaatkan media pembelajaran, 
sehingga proses pembelajaran menjadi kurang menarik. Model pembelajaran konvensional berupa ceramah kurang mampu memberikan stimulus pada peserta didik untuk aktif dalam proses pembelajaran. Oleh karena itu, model pembelajaran konvensional harus segera diganti dengan model pembelajaran yang menarik dan tepat sesuai dengan kebutuhan peserta didik. Penggunaan model pembelajaran yang bervariasi akan membantu peserta didik untuk aktif saat proses pembelajaran sehingga dapat mencapai tujuan pembelajaran.

Menurut Dave Meier (dalam Martinis Yamin, 2010: 75) Belajar adalah proses mengubah pengalaman menjadi pengetahuan, pengetahuan menjadi pemahaman, pemahaman menjadi kearifan, dan kearifan menjadi keaktifan. Pada hakikatnya pembelajaran yang efektif adalah pembelajaran yang dapat memberikan stimulus supaya peserta didik ikut terlibat secara aktif, salah satunya aktif bertanya. Bertanya adalah cara untuk mengungkapkan rasa keingintahuan akan jawaban yang belum diketahui. Pembelajaran yang dimulai dengan bertanya akan mendorong peserta didik untuk mencari tahu materi yang akan dipelajari sebelum dijelaskan oleh guru. Seperti yang dikemukakan oleh Kunandar (2008: 310) bahwa kegiatan bertanya berguna untuk memperoleh informasi administrasi maupun akademis, menguji pemahaman peserta didik, memecahkan persoalan yang terjadi, membangkitkan respon peserta didik, mengetahui seberapa jauh keingintahuan peserta didik, mengetahui hal-hal yang telah diketahui peserta didik, memfokuskan perhatian peserta didik pada sesuatu yang dikehendaki oleh guru, membangkitkan lebih banyak pertanyaan dari peserta didik, serta mengingatkan kembali pengetahuan yang telah diperoleh peserta didik.

Salah satu model pembelajaran adalah model Active Learning dengan teknik Learning Starts With A Question. Model pembelajaran aktif adalah model pembelajaran yang menekankan pada keaktifan peserta didik secara fisik, mental, intelektual, dan emosional untuk memperoleh hasil belajar berupa perpaduan antara kognitif, afektif, dan psikomotor (Uzer Usman, 2002: 22), sedangkan teknik Learning Starts With A Question menekankan pada aktivitas bertanya sebelum guru menjelaskan materi pelajaran. Model pembelajaran ini merupakan model pembelajaran yang berpusat pada aktivitas peserta didik. Langkah-langkah pelaksanaan Learning Starts With A Question yaitu peserta didik membaca terlebih dahulu materi pelajaran sebelum dijelaskan oleh guru. Membaca merupkan hal yang penting dalam pelaksanaan model pembelajaran ini, karena dengan membaca maka peserta didik dapat menemukan informasi yang diperlukan dan dapat menemukan bagian materi yang belum mereka pahami. Setelah peserta didik selesai membaca materi, kemudian peserta didik membuat daftar pertanyaan tentang bagian materi yang belum mereka pahami dan menanyakannya kepada guru atau forum di kelas. Peserta didik diberi kesempatan untuk menjawab atau mengemukakan pendapat atas pertanyaan-pertanyaan yang diajukan, sehingga melatih peserta didik berpikir untuk memecahkan jawaban dari pertanyaan-pertanyaan tersebut. Guru memulai pelajaran dengan mengklarifikasi jawaban-jawaban tersebut dan menjawab pertanyaan yang belum terjawab oleh 
peserta didik. Proses pembelajaran berpusat pada peserta didik, sedangkan guru menjadi fasilitator dan moderator selama proses pembelajaran berlangsung.

Berdasarkan pengamatan terhadap proses pembelajaran yang dilakukan saat observasi di kelas XI IPS 3 SMA Negeri 5 Yogyakarta pada mata pelajaran akuntansi ditemukan beberapa kendala, yaitu aktivitas peserta didik rendah selama proses pembelajaran walaupun guru telah mendorong mereka untuk berani bertanya, menjawab, atau menyanggah pernyataan. Peserta didik cenderung lebih memilih untuk diam atau bertanya kepada teman di luar jam pelajaran daripada bertanya kepada guru saat menemui kesulitan dalam pembelajaran. Aktivitas peserta didik yang terlihat selama proses pembelajaran hanya mendengarkan dan beberapa ada yang mencatat.

Berdasarkan pengamatan terhadap proses pembelajaran yang dilakukan peneliti dan melalui wawancara dengan guru mata pelajaran akuntansi di kelas XI IPS 3 SMA Negeri 5 Yogyakarta tahun ajaran 2013/2014, masih ada peserta didik yang aktivitas belajarnya rendah. Terlihat ketika guru menjelaskan materi pelajaran, dari 22 peserta didik di kelas hanya 13 peserta didik atau 59,09\% yang aktif memperhatikan. Sisanya, yaitu sebanyak 9 peserta didik atau $40,91 \%$ tidak memperhatikan saat guru menjelaskan materi pelajaran. Selama proses pembelajaran berlangsung, peserta didik yang terlihat aktif bertanya hanya 10 peserta didik atau 45,45\% sedangkan sisanya sebanyak 12 peserta didik atau 54,54\% masih terlihat pasif untuk bertanya kepada guru atau forum di kelas. Ketika guru memberikan tugas, peserta didik yang terlihat mengerjakan hanya 15 peserta didik atau $68,18 \%$ sedangkan sisanya sebanyak 7 peserta didik atau $31,82 \%$ tidak mau mengerjakan tugas dan memilih untuk menunggu jawaban dari teman.

Cara mengatasi masalah tersebut dapat dilakukan dengan mengimplementasikan model pembelajaran yang dapat meningkatkan aktivitas belajar peserta didik yaitu model Active Learning dengan teknik Learning Starts With A Question. Model pembelajaran tersebut mudah untuk diterapkan, akan tetapi masih jarang guru yang menggunakan. Berdasarkan latar belakang permasalahan tersebut maka peneliti merasa tertarik untuk melakukan penelitian dengan judul "Implementasi Model Active Learning dengan Teknik Learning Starts With A Question untuk Meningkatkan Aktivitas Belajar Akuntansi Peserta Didik Kelas XI IPS 3 SMA Negeri 5 Yogyakarta Tahun Ajaran 2013/2014”.

\section{METODE PENELITIAN}

\section{Tempat dan Waktu Penelitian}

Penelitian ini dilaksanakan di kelas XI IPS 3 SMA Negeri 5 Yogyakarta yang beralamat di Jalan Nyi Pembayun 39 Kotagede, Yogyakarta. Waktu penelitian ini dilaksanakan pada bulan Januari 2014.

\section{Desain Penelitian}

Penelitian ini termasuk ke dalam Penelitian Tindakan Kelas (Classroom Action Research). Penelitian Tindakan Kelas merupakan suatu pencermatan terhadap kegiatan belajar berupa sebuah tindakan, yang sengaja dimunculkan dan terjadi dalam sebuah kelas secara bersama Suharsimi Arikunto (2008: 3). Kemmis dan Taggart dalam Rochiati Wiriaatmadja (2009: 66) menyatakan ciri penelitian tindakan kelas adalah digunakannya prosedur kerja siklus spiral dalam suatu penelitian yang terdiri 
dari 4 tahap, yaitu perencanaan, pelaksanaan, pengamatan, dan refleksi.

Bagan spiral Kemmis dan Taggart adalah sebagai berikut:

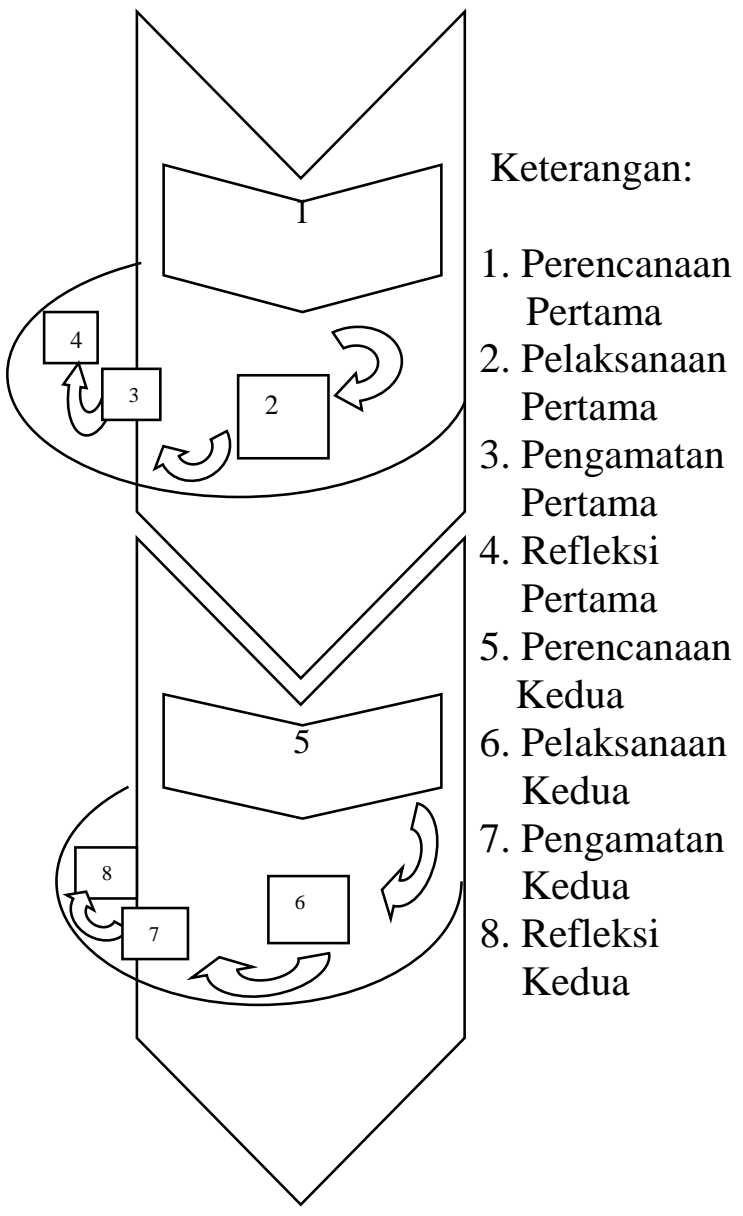

Gambar 1. Proses Penelitian Tindakan Model Kemmis dan Taggart (Rochiati Wiriaatmadja, 2009: 66)

\section{Subjek Penelitian}

Subjek dalam penelitian ini adalah seluruh peserta didik kelas XI IPS 3 SMA Negeri 5 Yogyakarta tahun ajaran 2013/2014 yang terdiri dari 22 peserta didik.

\section{Prosedur Penelitian}

Ciri khusus dari Penelitian Tindakan Kelas adalah adanya tindakan yang nyata.
Adapun langkah-langkah yang ditempuh dalam pelaksanaan penelitian:

a. Siklus I

1) Perencanaan Tindakan

2) Pelaksanaan Tindakan

3) Pengamatan

4) Refleksi

b. Siklus II

Langkah-langkah siklus II sama dengan siklus I yaitu perencanaan tindakan, pelaksanaan, pengamatan, dan refleksi. Dilakukan perbaikan atas kelemahan yang terjadi pada siklus I.

\section{Data, Intrumen, dan Teknik Pengum- pulan}

a. Data

Jenis data yang diperoleh dari observasi dan angket merupakan data kuantitatif. Teknik pengumpulan data dalam penelitian ini dilakukan dengan menggunakan observasi dan angket. Instrumen penelitian yang digunakan adalah lembar observasi, angket, dan catatan lapangan. Lembar observasi yang digunakan bersifat terstruktur, yaitu sudah terdapat pedomanpedoman berupa garis besar atau butir-butir umum kegiatan yang akan diobservasi (Nana Syaodih Sukmadinata, 2009: 221). Angket yang digunakan adalah bentuk jawaban tertutup, yaitu sudah tersedia alternatif pilihan jawaban. Catatan lapangan berupa formulir yang digunakan sebagai pencatat berita acara pelaksanaan pembelajaran.

b. Teknik Analisis Data

Teknik analisis data yang digunakan dalam penelitian ini adalah teknik analisis data deskriptif kuantitatif dengan persentase. Data yang diperoleh dari lembar observasi dan angket selanjutnya akan dianalisis untuk mengetahui persentase skor Aktivitas 
Belajar Akuntansi peserta didik. Rumus untuk menghitung persentase skor aktivitas belajar peserta didik pada setiap aspek yang diamati:

Skor Aktivitas Belajar Akuntansi Peserta didik Skor Maksimum

\section{Indikator Keberhasilan}

Peserta didik secara individual mencapai minimal $75 \%$ dan secara rata-rata kelas dalam pembelajaran Akuntansi mencapai minimal $75 \%$. Kriteria keberhasilan tindakan untuk masing-masing indikator sebagai berikut:

a. Aktivitas Visual dikatakan berhasil jika minimal $75 \%$ peserta didik melakukan aktivitas visual, yaitu:

1) Membaca materi pelajaran

2) Memperhatikan guru menjelaskan materi

b. Aktivitas Lisan dikatakan berhasil jika minimal $75 \%$ peserta didik melakukan aktivitas lisan, yaitu:

1) Bertanya kepada guru atau forum di kelas

2) Mengemukakan pendapat

c. Aktivitas Mendengarkan dikatakan berhasil jika minimal $75 \%$ peserta didik melakukan aktivitas mendengarkan, yaitu:

1) Mendengarkan ketika peserta didik lain bertanya

2) Mendengarkan ketika peserta didik lain mengemukakan pendapat

d. Aktivitas Menulis dikatakan berhasil jika minimal $75 \%$ peserta didik melakukan aktivitas menulis, yaitu:

1) Menulis pertanyaan materi yang belum dipahami

2) Mengerjakan tugas atau soal latihan yang diberikan oleh guru e. Aktivitas Menggambar dikatakan berhasil jika minimal $75 \%$ peserta didik melakukan aktivitas menggambar, yaitu:

1) Membuat kolom yang diperlukan

2) Memberi tanda atau menggarisbawahi bagian materi yang belum dipahami

f. Aktivitas Mental dikatakan berhasil jika minimal $75 \%$ peserta didik melakukan aktivitas mental, yaitu:

1) Berani menyampaikan pertanyaan yang telah ditulis

2) Mengerjakan tugas atau soal latihan yang diberikan oleh guru di depan kelas

HASIL PENELITIAN DAN PEMBAHASAN

Hasil Observasi Aktivitas Belajar Akuntansi Peserta Didik

Pada siklus I sebanyak 8 peserta didik dari 22 jumlah peserta didik kelas XI IPS 3 secara individual telah mencapai kriteria minimal sebesar $75 \%$. Rata-rata Aktivitas Belajar Akuntansi peserta didik siklus I sebesar $66,48 \%$.

Pada siklus II semua peserta didik secara individual telah mencapai kriteria minimal sebesar $75 \%$. Rata-rata Aktivitas Belajar Akuntansi peserta didik siklus I sebesar $82,34 \%$.

Berdasarkan data hasil observasi siklus I dan siklus II dapat diketahui bahwa terjadi peningkatan persentase Aktivitas Belajar Akuntansi peserta didik dari siklus I ke siklus II selama implementasi Model Active Learning dengan Teknik Learning Starts With A Question. Hal ini terlihat dari peningkatan rata-rata Aktivitas Belajar Akuntansi peserta didik sebesar $15,86 \%$ di mana pada siklus I diperoleh persentase 
sebesar $66,48 \%$ dan pada siklus II menjadi sebesar $82,34 \%$

Untuk lebih jelasnya, berikut ini disajikan data Hasil Observasi Aktivitas Belajar Akuntansi Peserta Didik:

Tabel 1. Hasil Observasi Aktivitas Belajar Akuntansi Peserta Didik

\begin{tabular}{|c|c|c|c|c|c|}
\hline \multirow[b]{2}{*}{$\begin{array}{l}\mathrm{N} \\
\mathrm{o}\end{array}$} & \multirow[b]{2}{*}{$\begin{array}{c}\text { Asp } \\
\text { ek }\end{array}$} & \multirow[b]{2}{*}{ Indikator } & \multicolumn{2}{|c|}{ Persentase } & \multirow{2}{*}{$\begin{array}{c}\text { Pening } \\
\text { katan }\end{array}$} \\
\hline & & & $\begin{array}{l}\text { Siklu } \\
\text { sI }\end{array}$ & $\begin{array}{l}\text { Siklu } \\
\text { s II }\end{array}$ & \\
\hline 1. & \multirow[b]{2}{*}{$\begin{array}{c}\text { Visu } \\
\text { al }\end{array}$} & $\begin{array}{l}\text { Membaca } \\
\text { materi } \\
\text { pelajaran }\end{array}$ & $\begin{array}{c}61,3 \\
6 \%\end{array}$ & $\begin{array}{c}88,1 \\
0 \%\end{array}$ & $26,74 \%$ \\
\hline 2. & & $\begin{array}{l}\text { Memperhat } \\
\text { ikan guru } \\
\text { menjelaska } \\
\text { n materi }\end{array}$ & $\begin{array}{c}70,4 \\
5 \%\end{array}$ & $\begin{array}{c}83,3 \\
3 \%\end{array}$ & $12,88 \%$ \\
\hline 3. & \multirow[t]{2}{*}{$\begin{array}{c}\text { Lisa } \\
\mathrm{n}\end{array}$} & $\begin{array}{l}\text { Bertanya } \\
\text { kepada } \\
\text { guru atau } \\
\text { forum di } \\
\text { kelas } \\
\end{array}$ & $\begin{array}{c}61,3 \\
6 \%\end{array}$ & $\begin{array}{c}85,7 \\
1 \%\end{array}$ & $24,35 \%$ \\
\hline 4. & & $\begin{array}{l}\text { Mengemuk } \\
\text { akan } \\
\text { pendapat }\end{array}$ & $\begin{array}{c}56,8 \\
2 \%\end{array}$ & $\begin{array}{c}78,5 \\
7 \%\end{array}$ & $21,75 \%$ \\
\hline 5. & \multirow{2}{*}{$\begin{array}{c}\text { Men } \\
- \\
\text { deng } \\
\text { ar- } \\
\text { kan }\end{array}$} & $\begin{array}{l}\text { Mendengar } \\
\text { kan ketika } \\
\text { peserta } \\
\text { didik lain } \\
\text { bertanya }\end{array}$ & $\begin{array}{c}79,5 \\
5 \%\end{array}$ & $\begin{array}{c}85,7 \\
1 \%\end{array}$ & $6,16 \%$ \\
\hline 6. & & $\begin{array}{l}\text { Mendengar } \\
\text { kan ketika } \\
\text { peserta } \\
\text { didik lain } \\
\text { mengemuk } \\
\text { akan } \\
\text { pendapat }\end{array}$ & $\begin{array}{c}81,8 \\
2 \%\end{array}$ & $\begin{array}{c}83,3 \\
3 \%\end{array}$ & $1,51 \%$ \\
\hline 7. & $\begin{array}{l}\text { Me- } \\
\text { nulis }\end{array}$ & $\begin{array}{l}\text { Menulis } \\
\text { pertanyaan } \\
\text { materi } \\
\text { yang } \\
\text { belum } \\
\text { dipahami }\end{array}$ & $\begin{array}{c}54,5 \\
5 \%\end{array}$ & $\begin{array}{c}76,1 \\
9 \%\end{array}$ & $21,64 \%$ \\
\hline
\end{tabular}

\begin{tabular}{|c|c|c|c|c|c|}
\hline 8. & & $\begin{array}{l}\text { Mengerjak } \\
\text { an tugas } \\
\text { atau soal } \\
\text { latihan } \\
\text { yang } \\
\text { diberikan } \\
\text { oleh guru }\end{array}$ & $\begin{array}{c}79,5 \\
5 \%\end{array}$ & $\begin{array}{c}83,3 \\
3 \%\end{array}$ & $3,78 \%$ \\
\hline 9. & & $\begin{array}{l}\text { Membuat } \\
\text { kolom } \\
\text { yang } \\
\text { diperlukan }\end{array}$ & $\begin{array}{c}70,4 \\
5 \%\end{array}$ & $\begin{array}{c}88,1 \\
0 \%\end{array}$ & $17,65 \%$ \\
\hline $\begin{array}{l}1 \\
0 .\end{array}$ & $\begin{array}{l}\text { Men } \\
\text { g- } \\
\text { gam } \\
\text { bar }\end{array}$ & $\begin{array}{l}\text { Memberi } \\
\text { tanda atau } \\
\text { menggaris } \\
\text { bawahi } \\
\text { bagian } \\
\text { materi } \\
\text { yang } \\
\text { belum } \\
\text { dipahami }\end{array}$ & $\begin{array}{c}63,6 \\
4 \%\end{array}$ & $\begin{array}{c}80,9 \\
5 \%\end{array}$ & $17,31 \%$ \\
\hline $\begin{array}{l}1 \\
1 .\end{array}$ & & $\begin{array}{l}\text { Berani } \\
\text { menyampa } \\
\text { ikan } \\
\text { pertanyaan } \\
\text { yang telah } \\
\text { ditulis }\end{array}$ & $\begin{array}{c}65,9 \\
1 \%\end{array}$ & $\begin{array}{l}76,1 \\
9 \%\end{array}$ & $10,28 \%$ \\
\hline $\begin{array}{l}1 \\
2 .\end{array}$ & $\begin{array}{c}\text { Men } \\
\text { tal }\end{array}$ & $\begin{array}{l}\text { Mengerjak } \\
\text { an tugas } \\
\text { atau soal } \\
\text { latihan } \\
\text { yang } \\
\text { diberikan } \\
\text { oleh guru } \\
\text { di depan } \\
\text { kelas. }\end{array}$ & $\begin{array}{c}52,2 \\
7 \%\end{array}$ & $\begin{array}{c}78,5 \\
7 \%\end{array}$ & $26,30 \%$ \\
\hline \multicolumn{3}{|c|}{$\begin{array}{l}\text { Rata-rata Aktivitas } \\
\text { Belajar Akuntansi } \\
\text { peserta didik }\end{array}$} & $\begin{array}{c}66,48 \\
\%\end{array}$ & $\begin{array}{c}82,3 \\
4 \%\end{array}$ & $15,86 \%$ \\
\hline
\end{tabular}

Sumber: Data Primer yang Diolah

\section{Hasil Angket Aktivitas Belajar Akuntansi Peserta Didik}

Setiap akhir siklus I maupun siklus II dibagikan angket Aktivitas Belajar Akuntansi peserta didik. Angket dibagikan kepada peserta didik setelah proses pembelajaran selesai. Selanjutnya data dari siklus I dan siklus II kemudian diolah lebih 
lanjut untuk mendapatkan angka-angka yang lebih mudah untuk diinterpretasikan yaitu dengan cara memberikan skor sesuai dengan skor alternatif jawaban yang telah ditentukan.

Berdasarkan data hasil angket Aktivitas Belajar Akuntansi Peserta Didik siklus I dan siklus II dapat diketahui bahwa terjadi peningkatan persentase Aktivitas Belajar Akuntansi peserta didik dari siklus I ke siklus II selama implementasi Model Active Learning dengan Teknik Learning Starts With A Question. Hal ini terlihat dari peningkatan rata-rata Aktivitas Belajar Akuntansi peserta didik berdasarkan hasil angket sebesar $12,44 \%$ di mana pada siklus I diperoleh persentase sebesar $67,44 \%$ dan pada siklus II menjadi sebesar 79,88\%.

Berdasarkan data angket pada siklus I menunjukkan bahwa hanya ada 3 indikator Aktivitas Belajar Akuntansi yang memenuhi kriteria minimal yaitu indikator mendengarkan ketika peserta didik lain bertanya $(82,39 \%)$, mendengarkan ketika peserta didik lain mengemukakan pendapat $(85,80 \%)$, dan mengerjakan tugas atau soal latihan yang diberikan oleh guru $(75,76 \%)$. Pada siklus II terdapat perubahan di mana semua indikator Aktivitas Belajar Akuntansi peserta didik telah mencapai kriteria minimal yang telah ditentukan yaitu sebesar $75 \%$. Selain itu, semua indikator angket juga mengalami peningkatan dari siklus I ke siklus II.

Untuk lebih jelasnya, berikut ini disajikan data Hasil Angket Aktivitas Belajar Akuntansi Peserta Didik siklus I dan siklus II:
Tabel 2. Hasil Angket Aktivitas Belajar Akuntansi Peserta Didik

\begin{tabular}{|c|c|c|c|c|c|}
\hline \multirow[b]{2}{*}{$\begin{array}{l}\mathrm{N} \\
\mathrm{o}\end{array}$} & \multirow[b]{2}{*}{$\begin{array}{c}\text { Asp } \\
\text { ek }\end{array}$} & \multirow[b]{2}{*}{ Indikator } & \multicolumn{2}{|c|}{ Persentase } & \multirow{2}{*}{$\begin{array}{c}\text { Peningk } \\
\text { atan }\end{array}$} \\
\hline & & & $\begin{array}{c}\text { Sikl } \\
\text { us I }\end{array}$ & $\begin{array}{l}\text { Sikl } \\
\text { us II }\end{array}$ & \\
\hline 1. & \multirow{2}{*}{$\begin{array}{c}\text { Visu } \\
\text { al }\end{array}$} & $\begin{array}{l}\text { Membaca } \\
\text { materi } \\
\text { pelajaran }\end{array}$ & $\begin{array}{c}55,6 \\
8 \%\end{array}$ & $\begin{array}{c}80,3 \\
6 \%\end{array}$ & $24,68 \%$ \\
\hline 2. & & $\begin{array}{l}\text { Memperhat } \\
\text { ikan guru } \\
\text { menjelaska } \\
\text { n materi }\end{array}$ & $\begin{array}{c}69,3 \\
2 \%\end{array}$ & $\begin{array}{c}78,5 \\
7 \%\end{array}$ & $9,25 \%$ \\
\hline 3. & \multirow[t]{2}{*}{$\begin{array}{c}\text { Lisa } \\
\mathrm{n}\end{array}$} & $\begin{array}{l}\text { Bertanya } \\
\text { kepada } \\
\text { guru atau } \\
\text { forum di } \\
\text { kelas }\end{array}$ & $\begin{array}{c}72,1 \\
6 \%\end{array}$ & $\begin{array}{c}80,9 \\
5 \%\end{array}$ & $8,79 \%$ \\
\hline 4. & & $\begin{array}{l}\text { Mengemuk } \\
\text { akan } \\
\text { pendapat }\end{array}$ & $\begin{array}{c}60,8 \\
0 \%\end{array}$ & $\begin{array}{l}77,3 \\
8 \%\end{array}$ & $16,58 \%$ \\
\hline 5. & \multirow{2}{*}{$\begin{array}{c}\text { Men } \\
- \\
\text { deng } \\
\text { ar- } \\
\text { kan }\end{array}$} & $\begin{array}{l}\text { Mendengar } \\
\text { kan ketika } \\
\text { peserta } \\
\text { didik lain } \\
\text { bertanya }\end{array}$ & $\begin{array}{c}82,3 \\
9 \%\end{array}$ & $\begin{array}{c}83,9 \\
3 \%\end{array}$ & $1,54 \%$ \\
\hline 6. & & $\begin{array}{l}\text { Mendengar } \\
\text { kan ketika } \\
\text { peserta } \\
\text { didik lain } \\
\text { mengemuk } \\
\text { akan } \\
\text { pendapat }\end{array}$ & $\begin{array}{c}85,8 \\
0 \%\end{array}$ & $\begin{array}{c}86,9 \\
0 \%\end{array}$ & $1,10 \%$ \\
\hline 7. & \multirow{2}{*}{$\begin{array}{l}\text { Me- } \\
\text { nulis }\end{array}$} & $\begin{array}{l}\text { Menulis } \\
\text { pertanyaan } \\
\text { materi } \\
\text { yang } \\
\text { belum } \\
\text { dipahami }\end{array}$ & $\begin{array}{c}59,6 \\
6 \%\end{array}$ & $\begin{array}{c}75,6 \\
0 \%\end{array}$ & $15,94 \%$ \\
\hline 8. & & $\begin{array}{l}\text { Mengerjak } \\
\text { an tugas } \\
\text { atau soal } \\
\text { latihan } \\
\text { yang } \\
\text { diberikan } \\
\text { oleh guru }\end{array}$ & $\begin{array}{c}75,7 \\
6 \%\end{array}$ & $\begin{array}{c}87,7 \\
0 \%\end{array}$ & $11,94 \%$ \\
\hline 9. & \multirow[t]{2}{*}{$\begin{array}{l}\text { Men } \\
\text { g- } \\
\text { gam } \\
\text { bar }\end{array}$} & $\begin{array}{l}\text { Membuat } \\
\text { kolom } \\
\text { yang } \\
\text { diperlukan }\end{array}$ & $\begin{array}{c}59,6 \\
6 \%\end{array}$ & $\begin{array}{c}77,3 \\
8 \%\end{array}$ & $17,72 \%$ \\
\hline 1 & & Memberi & 65,3 & 76,7 & $11,45 \%$ \\
\hline
\end{tabular}




\begin{tabular}{|c|c|c|c|c|c|}
\hline 0. & & $\begin{array}{l}\text { tanda atau } \\
\text { menggaris } \\
\text { bawahi } \\
\text { bagian } \\
\text { materi } \\
\text { yang } \\
\text { belum } \\
\text { dipahami }\end{array}$ & $4 \%$ & $9 \%$ & \\
\hline $\begin{array}{l}1 \\
1 .\end{array}$ & \multirow[b]{2}{*}{$\begin{array}{c}\text { Men } \\
\text { tal }\end{array}$} & $\begin{array}{l}\text { Berani } \\
\text { menyampa } \\
\text { ikan } \\
\text { pertanyaan } \\
\text { yang telah } \\
\text { ditulis }\end{array}$ & $\begin{array}{c}66,4 \\
8 \%\end{array}$ & $\begin{array}{c}75,6 \\
0 \%\end{array}$ & $9,12 \%$ \\
\hline $\begin{array}{l}1 \\
2 .\end{array}$ & & $\begin{array}{l}\text { Mengerjak } \\
\text { an tugas } \\
\text { atau soal } \\
\text { latihan } \\
\text { yang } \\
\text { diberikan } \\
\text { oleh guru } \\
\text { di depan } \\
\text { kelas. }\end{array}$ & $\begin{array}{c}56,2 \\
5 \%\end{array}$ & $\begin{array}{l}77,3 \\
8 \%\end{array}$ & $21,13 \%$ \\
\hline \multicolumn{3}{|c|}{$\begin{array}{l}\text { Rata-rata Aktivitas } \\
\text { Belajar Akuntansi } \\
\text { peserta didik }\end{array}$} & $\begin{array}{c}67,44 \\
\%\end{array}$ & $\begin{array}{c}79,88 \\
\%\end{array}$ & $12,44 \%$ \\
\hline
\end{tabular}

Sumber: Data Primer yang Diolah

\section{SIMPULAN DAN SARAN}

\section{Simpulan}

Berdasarkan hasil penelitian dapat disimpulkan bahwa Implementasi Model Active Learning dengan Teknik Learning Starts with a Question dapat Meningkatkan Aktivitas Belajar Akuntansi Peserta Didik Kelas XI IPS 3 SMA Negeri 5 Yogyakarta Tahun Ajaran 2013/2014. Hal tersebut dibuktikan dengan adanya peningkatan persentase rata-rata tiap aspek Aktivitas Belajar Akuntansi peserta didik yang diambil dengan lembar observasi, yaitu ratarata aspek Aktivitas Visual pada siklus I sebesar $65,91 \%$ dan siklus II naik menjadi sebesar 85,71\%. Rata-rata aspek Aktivitas Lisan pada siklus I sebesar $59,09 \%$ dan siklus II naik menjadi $82,14 \%$. Rata-rata aspek Aktivitas Mendengarkan pada siklus I sebesar $80,68 \%$ dan siklus II naik menjadi 84,52\%. Rata-rata Aspek Menulis pada siklus I sebesar $67,05 \%$ dan siklus II naik menjadi 79,76\%. Rata-rata aspek Menggambar pada siklus I sebesar 67,05\% dan siklus II naik menjadi $84,52 \%$. Rata-rata aspek Mental pada siklus I sebesar 59,09\% dan siklus II naik menjadi 77,38\%.

Peningkatan tersebut juga dapat dilihat dari masing-masing indikator Aktivitas Belajar Akuntansi peserta didik sebagai berikut:

a. Aspek Aktivitas Visual, indikator membaca materi pelajaran pada siklus I sebesar $61,36 \%$ meningkat menjadi sebesar $88,10 \%$ pada siklus II. Indikator memperhatikan guru menjelaskan materi pada siklus I sebesar 70,45\% meningkat pada siklus II menjadi sebesar 83,33\%.

b. Aspek Lisan, indikator bertanya kepada guru atau forum di kelas pada siklus I sebesar $61,36 \%$ meningkat menjadi sebesar $85,71 \%$ pada siklus II. Indikator mengemukakan pendapat pada siklus I sebesar $56,82 \%$ meningkat pada siklus II menjadi sebesar 78,57\%.

c. Aspek Mendengarkan, indikator mendengarkan ketika peserta didik lain bertanya pada siklus I sebesar 79,55\% meningkat menjadi sebesar $85,71 \%$ pada siklus II. Indikator mendengarkan ketika peserta didik lain mengemukakan pendapat pada siklus I sebesar $81,82 \%$ meningkat pada siklus II menjadi sebesar $83,33 \%$.

d. Aspek Menulis, indikator menulis pertanyaan materi yang belum dipahami pada siklus I sebesar 54,55\% meningkat menjadi sebesar 76,19\% pada siklus II. Indikator mengerjakan tugas atau soal latihan yang diberikan oleh guru pada 
siklus I sebesar 79,55\% meningkat pada siklus II menjadi sebesar 83,33\%.

e. Aspek Menggambar, indikator membuat kolom yang diperlukan pada siklus I sebesar $70,45 \%$ meningkat menjadi sebesar $88,10 \%$ pada siklus II. Indikator memberi tanda atau menggarisbawahi bagian materi yang belum dipahami pada siklus I sebesar 63,64\% meningkat pada siklus II menjadi sebesar 80,95\%.

f. Aspek Mental, indikator berani menyampaikan pertanyaan yang telah ditulis pada siklus I sebesar 65,91\% meningkat menjadi sebesar $76,19 \%$ pada siklus II. Indikator Mengerjakan tugas atau soal latihan yang diberikan oleh guru di depan kelas pada siklus I sebesar $52,27 \%$ meningkat pada siklus II menjadi sebesar 78,57\%.

Berdasarkan hasil angket yang dibagikan kepada peserta didik dapat disimpulkan bahwa terjadi peningkatan skor persentase rata-rata Aktivitas Belajar Akuntansi peserta didik sebesar $12,44 \%$ di mana skor pada siklus I sebesar $67,44 \%$ dan meningkat pada siklus II menjadi sebesar 79,88\%.

\section{Saran}

a. Bagi Guru

1) Guru hendaknya menggunakan variasi model pembelajaran yang dapat membantu peserta didik mengembangkan potensi yang dimiliki sehingga dapat tercipta suasana pembelajaran yang kondusif.

2) Penggunaan Model Active Learning dengan Teknik Learning Starts With A Question dapat dijadikan salah satu alternatif dalam proses pembelajaran akuntansi. Model pembelajaran ini diharapkan dapat memberikan variasi dalam pembelajaran dan dapat meningkatkan aktivitas belajar peserta didik.

b. Bagi Peserta Didik

1) Peserta didik hendaknya meningkatkan aktivitas belajarnya sehingga dapat berpartisipasi aktif selama proses pembelajaran.

2) Peserta didik hendaknya memiliki keberanian dan rasa percaya diri saat mengemukakan pendapatnya dalam proses pembelajaran sehingga hasil belajar dapat optimal.

3) Peserta didik perlu berlatih untuk membangun interaksi dalam belajar, baik kepada guru maupun kepada peserta didik lain sehingga proses pembelajaran dapat berlangsung secara dua arah.

c. Bagi Penelitian Selanjutnya

1) Peneliti yang akan melakukan penelitian tindakan kelas, khususnya dengan teknik Learning Starts With A Question hendaknya mempersiapkan segala sesuatunya dengan matang, terutama komunikasi dengan guru mata pelajaran yang bersangkutan.

2) Untuk penelitian yang akan datang diharapkan dapat lebih teliti dalam observasi sehingga dapat diperoleh data yang benar-benar mewakili kondisi peserta didik selama proses pembelajaran berlangsung.

\section{DAFTAR PUSTAKA}

Abu Ahmadi \& Nur Uhbiyati. (2003). Ilmu Pendidikan. Jakarta: Rineka Cipta.

Kunandar. (2008). Guru Profesional: Implementasi Kurikulum Tingkat Satuan Pendidikan (KTSP) dan 
Sukses dalam Sertifikasi Guru.

Jakarta: PT RajaGrafindo Persada.

Martinis Yamin. (2010). Kiat Membelajarkan Siswa. Jakarta:

Gaung Persada Press.

Nana Syaodih Sukmadinata. (2009). Metode Penelitian Pendidikan. Bandung: PT Remaja Rosdakarya.

Oemar Hamalik. (2009). Dasar-Dasar Pengembangan Kurikulum. Bandung: PT Remaja Rosdakarya.

Rochiati Wiriaatmadja. (2009). Metode Penelitian Tindakan Kelas: untuk Meningkatkan Kinerja Guru dan Dosen. Bandung: PT Remaja Rosdakarya.

Suharsimi Arikunto. (2008). Penelitian Tindakan Kelas. Jakarta: PT Bumi Aksara

Uzer Usman. (2002). Menjadi Guru Profesional. Bandung: PT Remaja Rosdakarya. 